\title{
PENGEMBANGAN MATERI AJAR ANIMASI BAHASA INGGRIS BAGI ANAK USIA DINI DI KOTA BENGKULU
}

\author{
Asiyah \\ Fakultas Tarbiyah \& Tadris, IAIN Bengkulu \\ E-mail: asiyah2710@gmail.com \\ Fatrica Syafri \\ Fakultas Tarbiyah \& Tadris, IAIN Bengkulu \\ E-mail: ricasyafri92@gmail.com \\ M. Arif Rahman Hakim \\ Fakultas Tarbiyah \& Tadris, IAIN Bengkulu \\ E-mail: arifelsiradj@iainbengkulu.ac.id \\ Orcid ld: 0000-0002-2128-2583
}

Article received: 11 Januari 2018, Review process:06 Februari 2018.

Article published: 30 Maret 2018

\begin{abstract}
Abstrak
Pendidikan dan pembelajaran bahasa Inggris didasari suatu pemikiran bahwa belajar bahasa asing atau bahasa kedua akan lebih baik bila dimulai lebih awal. Banyak asumsi tentang usia dan pembelajaran bahasa antara lain adalah anak-anak belajar bahasa lebih baik dari pebelajar dewasa, pembelajaran bahasa asing disekolah sebaiknya dimulai seawal mungkin, lebih mudah menarik perhatian dan minat anak-anak daripada orang dewasa. Pada saat ini di Indonesia telah banyak berkembang play group dan taman kanakkanak yang memberikan pembelajaran Bahasa Inggris kepada anak usia dini. Mereka yang terlibat didalamnya sangat perlu untuk memahami teori mengenai pengetahuan terkait pendidikan Bahasa Inggris khusus siswa usia dini namun kenyataannya masih banyak sekolah yang kesulitan untuk menemukan materi yang sesuai dengan apa yang didinginkan oleh siswa mereka. Hal ini seringkali dirasakan oleh sekolah Raudhatul Athfal di kota Bengkulu. Dalam penelitian ini, para peneliti mengembangkan bahan ajar yang dalam bentuk animasi dan lembar kerja siswa yang berguna untuk melengkapi dan menutupi kekurangan dari bahan ajar utama dari subjek Bahasa Inggris. Produk akhir dalam penelitian ini dikembangkan berdasarkan analisis kebutuhan siswa dan guru pada Raudhatul Athfal sederajat di kota Bengkulu
\end{abstract}

Kata Kunci: Pengajaran Bahasa Inggris, siswa usia dini, media pembelajaran animasi, EYL

\section{PENDAHULUAN}

Pendidikan dan pembelajaran bahasa Inggris didasari suatu pemikiran bahwa belajar bahasa asing atau bahasa kedua akan lebih baik bila dimulai lebih awal (Hammerby, 1982: 265). Banyak asumsi tentang usia dan pembelajaran bahasa antara lain adalah anak-anak belajar bahasa lebih baik dari pebelajar dewasa, pembelajaran bahasa asing disekolah sebaiknya dimulai seawal mungkin, lebih mudah menarik perhatian dan minat anak-anak daripada orang dewasa seperti diungkapkan oleh Ur (1996: 296). Asumsi tersebut belum dikomfirmasi dengan 
penelitian walaupun dari pengalaman kelihatannya pembelajar anak-anak lebih baik dan ternyata ada bukti bahwa lebih tua usia anak lebih efektif dia belajar bahasa (Ur: 1996 ).

Pada saat ini di Indonesia telah banyak berkembang play group dan taman kanak- kanak yang memberikan pembelajaran Bahasa Inggris kepada anak usia dini. Mereka yang terlibat didalamnya sangat perlu untuk memahami teori mengenai pengetahuan terkait perkembangan anak. Dalam hal perilaku, pembelajar usia dini biasanya masih memiliki sifat motorik. Mereka belum benar-benar memahami hal- hal yang terjadi dan belum berpikir secara konseptual. Belajar bahasa terjadi karena adanya interaksi. Dengan bertambahnya usia, terjadi perkembangan bahasa dan konsep dengan cepat. Namun pada level ini, pembelajar usia dini juga masih bersifat egosentris. Mereka sudah mulai menggunakan logika, namun masih sering memfokuskan perhatian untuk satu hal saja pada saat tertentu. Misalnya, mereka dapat membedakan warna dan ukuran, tetapi masih sulit bagi mereka untuk membedakan warna dan ukuran sesuatu secara bersamaan.Piaget mengemukakan suatu teori psikologi perkembangan yang berhubungan dengan unsur kognitif.

Menurut Piaget (1969), anak belajar dari lingkungan disekitarnya dengan cara mengembangkan apa yang sudah dimiliki dan akan berinteraksi dengan apa yang ditemui disekitarnya. Dalam berinteraksi, mereka akan melakukan suatu tindakan agar bisa memecahkan masalahnya dan disinilah terjadi proses belajar. Terkait hal ini, Piaget kembali menambahkan terdapat empat fase perkembangan perkembangan anak, yaitu:

1. Sensorymotor stage, dari lahir hingga usia 2 tahun;

2. Preoperational stage, usia 2-8 tahun

3. Concrete operational stage, usia 8-11 tahun

4. Formal stage, usia 11- 15 tahun atau lebih

Dengan memperhatikan keempat fase perkembangan tersebut, dapat kita lihat berada pada fase mana pembelajar anak usia dini di Indonesia, yaitu pada $2-8$ tahun (Preoperational stage). Pada stage ini, pikiran anak berkembang sedikit demi sedikit sesuai dengan perkembangan pengetahuan dan keterampilan intelektualnya menuju ketahap cara berpikir yang lebih logis dan formal.

Berdasarkan informasi di atas, peneliti merasa tertarik untuk membuat penelitian terkait tentang pembelajar bahasa Inggris usia dini. Oleh karena itu peneliti mencoba untuk mendapatkan informasi lebih lanjut menganai hal itu dengan mewawancarai beberapa guru 
bahasa Inggris yang mengajar dikelas pembelajar usia dini di beberapa Raudhatul Aftal di Bengkulu. Para guru tersebut mengatakan bahwa fenomena yang kerap kali terjadi di kelas yang mereka naungi adalah kurangnya bahan ajar yang sesuai dengan kebutuhan siswanya disekolahsekolah tersebut.

Berdasarkan latar belakang di atas, peneliti selanjutnya mengamati proses belajar mengajar di kelas bahasa Inggris bagi anak usia dini. Setelah mengamati, peneliti menemukan bahwa hanya ada beberapa pembelajar saja yang aktif di kelas. Mereka adalah siswa yang memang aktif berbicara, sementara yang lain yang merasa kurang tertarik dengan instruksi gurunya berdiam diri saja di kelas. Selain itu, peneliti juga menemukan bahwa tidak ada bahan ajar tertentu yang menarik perhatian seluruh siswa selama kegiatan kelas.

Masalah umum lainnya yang peneliti temukan dari beberapa kali observasi awal yang dilakukan adalah para pembelajar usia dini umumnya merasa lebih mudah untuk memahami berbahasa Inggris dengan menggunakan media audio visual. Mempertimbangkan hal-hal diatas, peneliti mengamati proses pengajaran pada beberapa kelas bahasa Inggris di lembaga-lembaga di Bengkulu yang memamng telah mengajarkan bahasa Inggris pada anak usia dini dan peneliti menemukan bahwa siswa usia dini sangat tertarik ketika guru mereka mengajarkan bahasa Inggris dengan menggunakan media audio visual. Namun permasalahan utama yang mereka hadapi adalah masih kurangnya materi bahan ajar yang secara khusus dirancang untuk para pembelajar bahasa Inggris usia dini yang memang berdasarkan konsep Islami, sehingga para guru tersebut hanya menggunakan materi bahan ajar umum yang mereka dapatkan dengan cara mengunduh video tersebut dari beberapa situs di internet. Berdasarkan hal ini, peneliti mempertimbangkan untuk mengembangkan bahan ajar audio visual lengkap beserta handbooknya yang nantinya didesain berdarkan konsep pembelajaran di lembaga anak usia dini Islam. Topik- yang nantinya akan dimasukkan ke dalam materi bahan ajar yang akan peneliti kembangkan nantinya akan berkontribusi pada pengembangan karakter pribadi para pembelajar usia dini tersebut dengan tetap memasukkan nilai-nilai kearifan lokal dalam materi bahan ajar tersebut. Dalam penelitian ini, peneliti juga akan melihat efek dari bahan audio visual ini nantinya, dalam perannya untuk meningkatkan kemampuan pembelajar usia dini tersebut dipandang dari aspek motivasi dan peningkatan kefasihan mereka dalam berbahasa Inggris. Nantinya, peneliti akan bertindak sebagai fasilitator dalam penelitian ini, dan akan mendapatkan bantuan dari guru bahasa Inggris yang berasal dari sekolah tersebut. 
Bahasa Inggris telah menjadi bahasa Internasional yang digunakan hampir disegala bidang kehidupan global. Bahasa Inggris juga telah menjadi bahasa dunia yang mendominasi era komunikasi untuk menghubungkan dan mentransfer ilmu ke seluruh dunia. Hal ini memberikan asumsi bahwa penguasaan bahasa Inggris merupakan kebutuhan yang sangat penting bagi masyarakat modern sekarang ini karena penguasaan terhadap bahasa Inggris memudahkan seseorang untuk memperluas pergaulannya di dunia internasional. Seperti yang dikatakan oleh Fromkin, "English has been called 'the lingua franca of the world" (1990: 259).

Kedudukan Bahasa Inggris di Indonesia merupakan bahasa asing pertama (the first foreign language). Kedudukan tersebut berbeda dengan bahasa kedua. Mustafa (2007) dalam hal ini menyatakan bahwa bahasa kedua adalah bahasa yang dipelajari anak setelah bahasa ibunya dengan ciri bahasa tersebut digunakan dalam lingkungan masyarakat sekitar. Sedangkan bahasa asing adalah bahasa negara lain yang tidak digunakan secara umum dalam interaksi sosial. Kedudukan bahasa Inggris di Indonesia tersebut mengakibatkan jarang digunakannya bahasa Inggris dalam interaksi sosial di lingkungan masyarakat sehingga bahasa Inggris merupakan bahasa yang sulit untuk dipelajari karena bahasa Inggris merupakan bahasa asing yang tidak digunakan sehari- hari dalam kehidupan masyarakat di Indonesia.

Faktanya, penguasaan bahasa Inggris adalah keterampilan yang sangat penting dalam era informasi dan komunikasi saat ini. Hal ini sangat menentukan bagaimana kita dapat berinteraksi secara global. Isu globalisasi saat ini menuntut sumberdaya manusia yang berkualitas dan mampu berkomunikasi dalam berbagai bahasa asing terutama bahasa Inggris sebagai bahasa internasional. Keahlian berbahasa asing ini diperlukan untuk menguasai ilmu pengetahuan, memiliki pergaulan luas dan karir yang baik. Hal ini membuat semua orang dari berbagai kalangan termotivasi untuk mengusai bahasa Inggris.

Kecenderungan masyarakat akan penguasaan bahasa asing tersebut, membuat mereka saling berlomba memasukkan anak-anak mereka untuk mempelajari bahasa Inggris sebagai salah satu keahlian yang dikembangkan. Hal ini berdasarkan asumsi bahwa anak lebih cepat belajar bahasa asing dari pada orang dewasa (Santrock, 2007:313). Sebuah penelitian yang dilakukan Johnson dan Newport, 1991 (Santrock, 2007:313) menunjukan bahwa imigran asal Cina dan Korea yang mulai tinggal di Amerika pada usia 3 sampai 7 tahun kemampuan bahasa Inggrisnya lebih baik dari pada anak yang lebih tua atau orang dewasa.

Penelitian lain yang menyatakan kebermanfaatan menguasai bahasa asing lebih dini, 
dinyatakan Mustafa (2007), bahwa anak yang menguasai bahasa asing memiliki kelebihan dalam hal intelektual yang fleksibel, keterampilan akademik, berbahasa dan sosial. Selain itu, anak akan memiliki kesiapan memasuki suatu konteks pergaulan dengan berbagai bahasa dan budaya. Sehingga ketika dewasa anak akan menjadi sumber daya manusia yang berkualitas dan bisa berprestasi. Mustafa (2007) menambahkan bahwa pemahaman dan apresiasi anak terhadap bahasa dan budayanya sendiri juga akan berkembang jika anak mempelajari bahasa asing sejak dini. Alasannya karena mereka akan memiliki akses yang lebih besar terhadap bahasa dan budaya asing.

Akan tetapi, pengajaran bahasa Inggris di Indonesia berbeda dengan pengajaran bahasa Inggris sebagai bahasa kedua di negara di mana bahasa Inggris sebagai media komunikasi. Di Indonesia, posisi bahasa Inggris merupakan bahasa asing pertama yang wajib diajarkan di SLTP dan SMU sedangkan di SD merupakan salah satu pelajaran muatan lokal yang sebenarnya bukan (atau) belum merupakan mata pelajaran wajib. Meskipun pada saat ini bahasa Inggris telah dicoba menjadi bahasa asing sebagai matapelajaran atau nantinya sebagai "medium" dalam bilingual education (Chamot, 1987). Bahkan, saat ini sedang dicoba program pembelajaran bilingual untuk matapelajaran matematika dan IPA di Sekolah Dasar kelas 4 dan 5 (42 SD di 30 propinsi).

Sebenarnya, tujuan pengajaran bahasa Inggris mencakup semua kompetensi bahasa, yaitu menyimak (listening), berbicara (speaking), membaca (reading), dan menulis (writing). Bahasa Inggris juga sangat berbeda dengan bahasa pertama anak- anak (bahasa Indonesia, Jawa, Sunda, dan bahasa daerah yang lain di Indonesia). Perbedaan kebahasaan ini penting untuk dipahami agar pembelajaran dapat dipertanggung jawabkan kebenarannya. Perbedaan tersebut antara lain: ucapan, ejaan, struktur bahasa, tekanan dan intonasi, kosakata, dan nilai kultur bahasa asing. Bahasa Inggris juga diketahui sebagai bahasa yang cermat waktu (tenses), cermat angka (singular-plural), dan cermat orang (feminine dan maskulin).

Bila kita berbicara mengenai pembelajaran bahasa Inggris untuk anak usia dini atau biasa disebut EYL (English for Young Learners), kita perlu memahami dulu siapa yang kita maksud dengan EYL. Menurut Suyanto (2008: 14), siswa EYL adalah pembelajar usia muda ang mempelajari bahasa Inggris. Mereka bisa diklasifikasikan sebagai anak-anak usia sekolah mulai dari TK dan Sekolah Dasar yang mendapatkan pelajaran bahsa Inggris disekolahnya. Secara umum mereka adalah pembelajar pemula, namun perlu diingat seorang guru EYL tidak dapat

Pengembangan Materi Ajar Animasi Bahasa Inggris Bagi Siswa Usia Dini di Kota Bengkulu
Asiyah, Fatrica Syafri dan M. Arif Rahman Hakim 
menyamaratakan mereka dengan memberi tugas dan kegiatan belajar yang sama. Kemampuan dan keterampilan anak yang berbeda dalam pembelajaran bahasa Inggris tentu juga berbeda.

Apa yang dapat diserap dan dilakukan oleh pemula berusia lima tahun berbeda dengan apa yang bisa dilakukan oleh siswa berusia 8 tahun, meskipun kesemuanya mereka itu masih tergolong dalam pembelajar usia dini. Selain perkembangannya yang tidak sama, beberapa dari mereka juga ada yang motivasi belajarnya sangat tinggi dan berkembang lebih cepat, terdapat juga perkembangannya yang perlahan-lahan secara bertahap dan motivasi belajar yang rendah sehingga perkembangannya menjadi lebih lambat dibanding pembelajar lain yang sebaya dengannya. Kaitannya dengan hal tersebut, Hakim dan Dian (2015: 32) percaya bahwa interaksi sosial dengan dengan sesama pembelajar lain, terutama dengan orang dewasa akan dapat menimbulkan ide-ide baru dan meningkatkan perkembangan intelektual pembelajar usia dini tersebut. Selanjutnya, Hakim dan Dian (2015: 30) berpendapat bahwa akan sangat penting bagi seorang guru yang menngajar pada anak usia dini untuk dapat menyediakan materi dan topic bahasa Inggris berdasarkan kondisi dan kebutuhan siswa karena terkadang ketika pelajar asing mempelajari bahasa Inggris, mereka masih merasa bingung mengenai apa yang harus mereka lakukan.

Perlu kita ketahui bahwa sebenarnya bahasa merupakan alat bagi anak untuk membuka peluang guna melakukan sesuatu dan untuk menata informasi melalui penggunaan kata-kata. Karena itu, tidak mengherankan jika sering kita temui anak yang berbicara pada dirinya sendiri ketika bermain, hal itu sering disebut sebagai bahasa pribadi (private speech). Dalam tingkat perkembangan ini dia mampu membedakan antara social speech untuk orang lain dan private speech untuk dirinya sendiri (Cameron, 2001).

Pada dasarnya yang perlu diingat sebagai salah satu tujuan penting dalam pembelajaran bahasa Inggris untuk anak usia dini adalah menumbuhkan minat anak dalam belajar bahasa Inggris. Untuk dapat mencapai tujuan tersebut kita perlu memahami karakteristik anak sehingga bisa memilih metode dan bahan pembelajaran yang tepat bagi mereka. Karena itu, sebelum menangani kelas EYL, hendaknya pengajar sudah memiliki bekal pengetahuan yang cukup tentang siswa yang akan mereka hadapi didalam kelas. Kelas EYL akan dapat menjadi pengalaman yang menyenangkan bagi anak, tetapi juga dapat juga menjadi pengalaman yang menakutkan bagi mereka.

Berdasarkan latar belakang di atas, tujuan dari penelitian ini adalah mengembangkan 
bahan ajar berupa video animasi dan buku pegangan siswa untuk pembelajar usia dini di RA Bengkulu dan setelahnya peneliti akan melihat dampak dari produk tersebut terhadap siswa secara motivasional maupun efek kelancaran berbahasa Inggris dari siswa tersebut.

\section{METODOLOGI}

Penelitian ini merupakan penelitian pengembangan (R\&D), yang dilakukan untuk mengembangkan bahan ajar bahasa Inggris untuk pembelajar usia dini. Borg dan Gall dalam Latief (2012: 171) menyatakan penelitian pengembangan pendidikan adalah salah satu desain penelitian yang bertujuan untuk mengembangkan dan memvalidasi produk pendidikan. Sementara Latief (2012: 171) mendefinisikan penelitian pengembangan pendidikan sebagai desain penelitian untuk mengembangkan produk pendidikan seperti kurikulum, silabus, buku teks, media pembelajaran, modul, instrumen penilaian dan lain-lain Penelitian ini akan dilakukan untuk merancang bahan ajar Bahasa Inggris untuk anak usia dini di RA Bengkulu, yang diharapkan sesuai dengan kebutuhan siswa di kelas Bahasa Inggris bagi pembelajar usia dini di RA Bengkulu. Berikut langkah-langkah yang penelitian pengembangan yang sudah didiadaptasi berdasarkan kebutuhan penelitian yang dimulai dari: Memperoleh informasi yang terdiri dari mengidentifikasi masalah, memilih sarana pemecahan masalah, dan kajian teori; memilih, menentukan konsep dan merangkai bahan ajar yang terdiri dari video animasi dan buku pegangan siswa; pengembangan materi; validasi oleh ahli untuk mendapatkan umpan balik; merevisi yang terdiri dari revisi materi berdasarkan verifikasi ahli; evaluasi yang terdiri dari percobaan, evaluasi, revisi, dan validasi berdasarkan masukan selama proses belajar mengajar yang didapat dari guru dan pihak sekolah dan penyelesaian yang terdiri dari pengembangan produk akhir bahan ajar Bahasa Inggris untuk anak usia dini.

Terkait analisis kebutuhan yang diberikan kepada siswa di kelas Raudhatul Athfal di Kota Bengkulu, peneliti memberikan kuesioner dan wawanacara kepada para siswa dan guru untuk mengetahui bahan ajar Bahasa Inggris yang dibutuhkan oleh siswa usia dini, pendapat siswa dan guru tentang kelas Bahasa Inggris, kegiatan dan minat siswa terhadap kelas Bahasa Inggris, pentingnya mengembangkan materi dan materi yang ada.

\section{HASIL DAN PEMBAHASAN}

\section{Hasil dari Analisis Kebutuhan}

Angket dibagikan kepada 3 guru bahasa Inggris pada 3 Raudhatul Athfal atau sederajat yang terdapat di kota Bengkulu dalam rangka untuk mengumpulkan semua informasi yang 
berhubungan dengan kebutuhan pembelajar usia dini dalam mengatasi masalah mereka pada pembelajaran Bahasa Inggris. Dalam penelitian ini, wawancara yang telah dilakukan meliputi tujuh poin analisis, yaitu ketertarikan siswa pada kegiatan belajar mengajar bahasa Inggris, ketertarikan siswa dalam belajar Bahasa Inggris, kemampuan dasar bahasa Inggris siswa, pendapat siswa tentang bahan ajar pada pembelajaran Bahasa Inggris, minat siswa pada pembelajaran yang menggunakan audio visual, ketertarikan siswa pada animasi, preferensi siswa pada ilustrasi bahan ajar Bahasa Inggris.

Berdasarkan data yang telah dikumpulkan para peneliti dari 60 siswa dari tiga Raudhatul Athfal di Kota Bengkulu, ditemukan bahwa ada 33, 33 \% atau 20 siswa menyatakan bahwa mereka sangat tertarik untuk belajar bahasa Inggris 58, $33 \%$ atau 35 siswa menyatakan bahwa mereka tertarik untuk belajar bahasa Inggris. Sedangkan, 6, 66 \% atau 4 siswa merasa kurang tertarik untuk belajar bahasa Inggris dan 1, $66 \%$ atau hanya satu siswa yang mengatakan bahwa dia tidak tertarik untuk belajar bahasa Inggris. Sebagian besar siswa mengaku bahwa belajar bahasa Inggris merupakan sesuatu yang menyenangkan. Di sisi lain, hampir seluruh siswa mengatakan bahwa mereka sangat tertarik untuk belajar Bahasa Inggris, namun itu tidak berarti bahwa belajar Bahasa Inggris itu mudah.

Berdasarkan data dari kuesioner, ditemukan bahwa ada 33,33\% dari mereka atau 20 siswa mengakui bahwa belajar Bahasa Inggris sangat sulit, $20 \%$ atau 15 siswa di antaranya mengatakan bahwa belajar Bahasa Inggris adalah sulit. Namun, ada 33,33 \% atau 20 siswa yang mengatakan bahwa belajar Bahasa Inggris kurang sulit dan 8,33\% dari mereka atau 5 siswa mengatakan bahwa belajar Bahasa Inggris tidak sulit. Jelas, keragaman antara perspektif siswa belajar Bahasa Inggris dipengaruhi oleh motivasi mereka, latar belakang pengetahuan dan keluarga. Terlepas dari fakta-fakta di atas, secara umum, peneliti menyimpulkan bahwa ada $33,33 \%$ dari siswa mengaku belajar Bahasa Inggris sulit bahkan sangat sulit. Fenomena ini terjadi karena metode pengajaran konvensional dan prosedur yang dilakukan oleh para guru Bahasa Inggris yang digunakan untuk menanamkan pola tata bahasa dalam awal proses belajar Bahasa Inggris di periode yang lama. Para siswa usia dini merasa bahwa mereka dibebani dengan metode Audio-lingual ini selama proses belajar mengajar di kelas. Oleh karena itu, tidak jarang Bahasa Inggris menjadi momok yang mengerikan dalam pikiran para siswa karena mereka harus menghafal pola dalam tata bahasa yang akhirnya mempengaruhi cara pandang mereka hingga mencapai usia dewasa, bahwa Bahasa Inggris adalah pelajaran yang sulit. 
Di bagian tentang pendapat siswa belajar keterampilan bahasa Inggris, ditemukan bahwa ada 16,66 \% dari mereka atau 10 siswa mengatakan bahwa belajar mendengar menjadi bagian yang sulit untuk dipelajari. Selain itu, ada 33,33 \% atau 20 mahasiswa mengatakan bahwa yang paling sulit dalam belajar keterampilan bahasa Inggris adalah berbicara dan 50\% atau 30 siswa mengatakan bahwa membaca atau mengeja menjadi sulit. Berdasarkan fakta-fakta di atas, peneliti menyimpulkan bahwa yang paling sulit dalam belajar kemampuan berbahasa Inggris adalah membaca atau mengeja. Pada dasarnya sebagian besar siswa usia dini mengalami kesulitan pada pembelajaran ini dikarenakan bahan-bahan ajar yang digunakan hanya berfokus pada hafalan-hafalan saja tanpa disertai sesuatu yang memang dapat membuat siswa usia dini tersebut tertarik. Dalam penelitian ini ditemukan bahwa ada bahan yang baik untuk siswa usia dini dalam belajar Bahasa Inggris tetapi kurangnya pada praktek yang sebenarnya. Di sisi lain, paara siswa juga tidak punya banyak waktu untuk belajar Bahasa Inggris disekolah karena hanya dipelajari 2 jam dalam satu minggu. Mereka terlalu fokus pada menghafal materi yang ada, padahal sebenarnya pembelajaran Bahasa Inggris untuk anak usia dini tidak ditekankan pada pengahafalan saja, melainkan pada materi bahan ajar menarik yang diharapkan dapat membantu siswa dapat mengingat sekaligus mempraktekkannya dalam kehidupan sehari-hari. Oleh karena itu, dalam penelitian ini, peneliti mengembangkan bahan ajar Bahasa Inggris audio visual sebagai bahan ajar pelengkap pengajaran Bahasa Inggris untuk pembelajar usia dini di Raudhatul Athfal sederajat di kota Bengkulu. Dengan pengembangan bahan ajar Bahasa Inggris berbasis audio visual, diharapkan nantinya produk ini akan mampu mengatasi masalah siswa usia dini dalam meningkatkan kemampuan berbahasa Inggrisnya dan membiarkan mereka berbicara secara bebas sambil bermain tanpa terlalu dibebani dengan pengahafalan pola tata bahasa.

Selain mengumpulkan analisis kebutuhan kepada siswa, para peneliti juga melakukan wawancara kepada para 6 orang guru yang mengajar Bahasa Inggris di Raudhatul Athfal di Kota Bengkulu. Wawancara yang dilakukan memiliki tujuan untuk mengumpulkan semua informasi yang berhubungan dengan proses belajar mengajar Bahasa Inggris pada perspektif guru serta akan menjadi dasar dalam mengembangkan bahan ajar Bahasa Inggris berbasis Audio Visual untuk pembelajar usia dini. Dalam proses wawancara ini, peneliti menentukan beberapa poin dari wawancara yang disampaikan yang meliputi pendapat guru tentang minat siswa dalam belajar Bahasa Inggris, ketersediaan materi Bahasa Inggris yang sesuai dengan kebutuhan siswa dalam belajar Bahasa Inggris. Selain itu, juga termasuk saran guru yang bersangkutan mengenai 
bahan yang akan dikembangkan untuk siswa usia dini dalam Bahasa Inggris, dan kendala yang ditemukan selama mengajar Bahasa Inggris bagi anak usia dini.

Hasil dari wawancara tersebut para guru menyatakan bahwa para siswanya selalu bersemangat ketika akan memulai pembelajaran Bahasa Inggris, meskipun terkadang dipertengahan pembelajaran para siswa mulai merasa bosan dan gampang teralihkan dengan aktivitas lain. Melalui fenomena ini, di setiap kelas Bahasa Inggris, siswa sangat antusias dalam setiap bagian dari pembelajaran Bahasa Inggris. Namun, peneliti cukup terkejut ketika guru Bahasa Inggris di enam Raudhatul Athfal mengatakan ketersediaan bahan ajar Bahasa Inggris disekolah mereka sangat terbatas. Kurangnya bahan ajar Bahasa Inggris, terutama untuk praktek yang sebenarnya, hal ini tentu menjadi kendala yang sangat urgent bagi pihak sekolah karena tidak bisa memenuhi kebutuhan para siswa, terutama untuk menutupi antusias mereka dalam proses belajar mengajar. Jumlah bahan ajar Bahasa Inggris yang terbatas akan berdampak terhadap ketidakefektifan proses belajar mengajar disekolah tersebut. Bahan yang digunakan untuk digunakan hampir keseluruhan difokuskan pada proses mengahafal, bahkan hampir tidak ada waktu untuk melaksanakan praktek secara langsung, tentu hal tidak memberikan banyak kesempatan bagi para siswanya untuk mengekspresikan kemampuan mereka dalam belajar Bahasa Inggris.

Oleh karena itu, ketika peneliti mengatakan kepada para guru tersebut bahwa peneliti akan mengembangkan bahan ajar Bahasa Inggris sebagai bahan ajar pelengkap yang sesuai dengan kebutuhan siswa usia dini disekola yang mereka ajar, guru-guru tersebut sangat mendukung dan merasa sangat setuju, antusias, dan bahagia. Ia berharap bahwa bahan yang akan dikembangkan dapat menutupi kebutuhan bahan ajar Bahasa Inggris dan memotivasi para siswa untuk lebih tertarik untuk belajar bahasa Inggris, serta dapat mengatasi dan memecahkan permasalahan para siswa dalam belajar Bahasa Inggris. Guru- guru tersebut juga mengatakan bahwa bahan yang tepat untuk Bahasa Inggris adalah bahan yang mewakili pada praktek yang sebenarnya, karena para siswa butuh pembelajaran yang menyenangkan serta memotivasi. Bahan ajar tersebut juga harus mencakup apa yang ada disekitar mereka dan komunikasi sehari-hari. Bahan ajar juga harus dapat difahami dengan mudah, sehingga para siswa dapat memahami dan mempraktekkan hasil pembelajaran tersebut dengan baik.

Guru menyarankan bahwa kegiatan yang sesuai dalam subjek Bahasa Inggris untuk siswa agar dapat mempraktekkan secara langsung dengan tahapan-tahapan yang sesuai dengan kaidah-

Pengembangan Materi Ajar Animasi Bahasa Inggris Bagi Siswa Usia Dini di Kota Bengkulu
Asiyah, Fatrica Syafri dan M. Arif Rahman Hakim 
kaidah pengajaran bahasa berbasis audio visual. Para guru juga menyarankan bahwa pada akhir sesi materi, peneliti harus menempatkan refleksi tentang apa yang telah dipelajari oleh siswa yang dalam bentuk bahasa lisan.

Pada akhir proses wawancara, peneliti menanyakan tentang kendala yang para guru seringkali temui selama proses pengajaran Bahasa Inggris pada siswa usia dini di Raudhatul Atfal mereka masing- masing. Para guru mengakui bahwa ada beberapa kendala yang mereka temui selama mengajar dan proses belajar Bahasa Inggris. Hambatan-hambatan umum seperti terbatasnya waktu bagi mereka untuk menyiapkan bahan ajar Bahasa Inggrisnya sendiri, terutama untuk menutupi kekurangan materi utama karena guru yang bersangkutan sangat sibuk dan mereka juga dituntut agar dapat mengajar pelajaran dan membimbing kegiatan siswa diluar Bahasa Inggris seperti pelajaran agama, membaca, dan lainnya. Para guru juga mengatakan bahwa para siswanya terkadang merasa bosan ditengah proses belajar mengajar Bahasa Inggris. Fenomena kerapkali ini terjadi karena bahan dalam buku utama yang memang cukup membosankan karena bahan berada dalam bentuk gambar hitam dan putih, sehingga siswa siswi mereka merasa tidak tertarik pada pelajaran dan gampang teralihkan pada kegiatan-kegiatan lain. Kendala lain yang di kemukakan oleh para guru adalah materi utama yang hanya memberikan sebagian kecil dari apa yang sebenarnya diinginkan siswa dalam pembelajaran Bahasa Inggris. Waktu yang terbatas ini tidak bisa mendorong siswa baik untuk berbicara sebanyak yang mereka bisa dan mengekspresikan secara bebas dengan bahasa lisan dari apa yang mereka pelajari dan praktekkan dalam komunikasi kehidupan nyata. Jadi guru merasa sulit untuk mengalokasikan waktu dan merevisi ulang untuk menutupi kebutuhan siswa pada pelajaran Bahasa Inggris di sekolahnya masing- masing.

Dalam rangka untuk membuat pengembangan bahan yang menarik, para guru mengatakan bahwa ilustrasi dalam bahan yang dikembangkan benar-benar diperlukan. Mereka mengatakan bahwa ilustrasi bisa membangun imajinasi siswa mereka tentang bagaimana memahami Bahasa Inggris dengan baik. Selain itu mereka juga menyatakan bahwa ilustrasi diperlukannya pengembangan dalam bahan ajar. Fenomena yang sering terjadi terkait pernyataan tersebut dikarenakan gaya belajar siswa yang memang berbeda, sehingga pengembangan ilustrasi dinilai sangat dibutuhkan.

Pada wawancara ini pada para guru terkait bentuk ilustrasi, preferensi mereka pada ilustrasi haruslah dalam bentuk gambar berwarna-warni dibandingkan dengan gambar hitam 
putih. Berdasarkan informasi itu, peneliti bisa mengembangkan animasi sebagai bahan ajar pelengkap pada mata pelajaran Bahasa Inggris yang tepat bagi para siswa usia dini di Raudhatul Athfal Kota Bengkulu

\section{Hasil dari Pengembangan Materi}

Rancangan pengembangan bahan ajar pelengkap pada pelajaran Bahasa Inggris ini difokuskan pada aktivitas melihat dan mendengar. Tidak hanya itu, materi-materi ini juga dapat memotivasi para siswa untuk mengeja dan membaca dan tentu saja bersumber dari silabus yang digunakan pada sekolah masing-masing. Bahan ajar pelengkap dalam pelajaran Bahasa Inggris ini terdiri dari animasi dan lembar kerja siswa. Topik yang dipilih dengan pertimbangan yang berkaitan dengan kebutuhan dan minat para siswa dan bertujuan memperkaya pengetahuan dalam mendukung kegiatan mereka sehari-hari.

\section{Hasil Validasi Ahli}

Langkah selanjutnya dari penelitian ini adalah validasi ahli. Ketika bagian pertama dari pengembangan sudah siap, peneliti berkonsultasi ke ahli untuk dievaluasi dan memastikan bahwa bahan-bahan tambahan yang berlaku untuk diterapkan kepada para siswa nantinya dapat sesuai dengan kebutuhan. Instrumen yang digunakan untuk mengevaluasi dan memvalidasi rancangan penelitian pengembangan ini berbentuk check list dan kolom saran. Setelah menyelesaikan draft awal dari bahan ajar yang peneliti kembangkan, peneliti memvalidasi rancangan para ahli. Untuk ahli pertama, ada dua karakteristik yang harus divalidasi dalam lima unit bahan yang dikembangkan. Kedua karakteristik tersebut adalah evaluasi pada isi, dan evaluasi bahasa.

Untuk evaluasi pada konten, secara umum, ahli mengatakan bahwa bahan yang sudah dikembangkan sangat baik dan tepat untuk diterapkan dalam proses belajar mengajar Bahasa Inggris bagi siswa usia dini yang sesuai dengan kurikulum dan silabus yang sedang digunakan. Para ahli juga mengklaim bahwa bahan ajar yang sudah dikembangkan sangat menarik. Ia percaya bahwa para siswa akan memiliki motivasi yang tinggi dan dapat menurunkan masalah mereka dalam belajar Bahasa Inggris melalui bahan ajar ini, karena bahan ajar yang terdiri dari video animasi 2D dan lembar kerja siswa diatur semenarik mungkin dengan urutan yang baik.

Secara khusus, para ahli memiliki beberapa pendapat dan saran untuk membuat bahanbahan yang sudah dikembangkan menjadi lebih baik. Untuk evaluasi pada konten, para ahli mengatakan pada awalnya materi yang digunakan belum mencakup kebutuhan para siswa dalam 
pembelajaran Bahasa Inggris. Lebih jauh para ahli berpendapat bhwa bahan ajar yang telah dikembangkan tersebut masih bersifat teoritis dan belum memberikan real life context yang diperlukan dalam pembelajaran Bahasa Inggris dan itu akan membingungkan para siswa dalam memahami makna dan tujuan dari bahan pembelajaran. Oleh karena itu, mereka menyarankan agar para peneliti dapat kembali memperjelas materi bahan ajar agar mudah dipahami, karena untuk siswa usia dini, sebenarnya materi yang dibahas tidak perlu terlalu sulit. Untuk bagian pertengahan dan akhir para ahli tidak menyarankan apa-apa. Mereka mengklaim bahwa materi dan konten yang terdapat dalam bahan ajar sudah sangat baik dan sesuai dengan kebutuhan para siswa dan guru. Namun, sebagai masukan tambahan, para ahli menyarankan peneliti untuk kembali mengevaluasi lebih spesifik tentang prosedur penyampaian materi dengan tata bahasa yang benar dan relevan dengan kebutuhan para siswa dan guru. Ia mengatakan beberapa materi yang telah disertakan pada bahan ajar masih bersifat terlalu umum, ia menyarankan agar peneliti memberikan materi ringan namun lebih spesifik agar para siswa dapat memahami materi tersebut dengan baik.

Untuk karakteristik kedua dalam proses validasi, yaitu evaluasi bahasa, para ahli mengatakan bahwa bahasa yang digunakan secara umum sudah baik. Oleh karena itu, mereka mengatakan bahwa tidak ada saran yang terlalu ditekankan pada bagian ini karena penggunaan bahasa dalam bahan-bahan yang sudah dikembangkan mudah untuk dipahami oleh siswa dan disertai kalimat dan tata bahasa sesuai dengan level pengetahuan para siswa. Untuk aspek strategi mengajar, secara umum, para ahli sangat tertarik pada strategi yang terdapat pada bahan ajar yang sudah dikembangkan. Menurut para ahli, strategi pengajaran tersebut telah sistematis dan bisa memotivasi siswa untuk lebih aktif dalam kegiatan pembelajaran Bahasa Inggris di Raudhatul Athfal. Penyampaian materi membuat konstruksi kerangka berpikir siswa menjadi jelas dan mudah untuk mengikuti, sehingga materi-materi yang disampaikan akan membuat para siswa lebih antusias dalam belajar. Terakhir, revisi dilakukan berdasarkan koreksi dan saran dari kedua ahli untuk membuat produk akhir yang lebih baik.

\section{Revisi Produk Bahan Ajar}

Setelah validasi dari para ahli, peneliti merevisi produk berdasarkan koreksi dan saran dari para ahli. Revisi yang dilakukan oleh para peneliti adalah tentang perubahan materi bahan ajar yang tidak sesuai dengan kebutuhan para siswa dan guru, kesalahan ejaan kata-kata, tanda baca, dan lain-lain. Semua bahan yang telah direvisi akan divalidasi untuk kedua kalinya para 
ahli agar membuat bahan-bahan yang telah dikembangkan dapat lebih dipahami dan memenuhi syarat. Oleh karena itu, peneliti berkonsultasi dengan ahli tentang kualitas konten, bahasa, strategi mengajar, dan kesesuaian dengan prinsip audio visual. Semua saran dari para ahli untuk bahan-bahan yang dikembangkan sangat berguna untuk membuat bahan-bahan dikembangkan menjadi lebih baik. Semua aspek menyangkut kelemahan bahan ajar tambahan yang dikembangkan telah didesain ulang berdasarkan saran dan telah divalidasi oleh kedua ahli. Kemudian, bahan ditingkatkan menjadi baik dan siap untuk di uji cobakan.

\section{Hasil Try-Out}

Untuk mengetahui penerapan bahan ajar yang dikembangkan, diperlukan uji coba produk di lapangan secara nyata di mana langkah ini dilakukan untuk mendapatkan beberapa informasi yang berkaitan dengan bahan-bahan yang sekali lagi perlu direvisi dan ditingkatkan dalam rangka mengetahui kesesuaian bahan yang dikembangkan untuk para siswa dan guru. Oleh karena itu, peneliti melakukan try-out pada para siswa tiga sekolah ssebagai representatif Raudhatul Athfal sederajat di kota Bengkulu pada 17 Juli, 18 Juli dan 25 Agustus 2017 dengan rincian sebagai berikut:

Tabel 1. Jadwal Pelaksanaan Uji Coba Produk di Raudhatul Athfal Bengkulu

\begin{tabular}{|l|l|l|l|}
\hline No & Hari/ Tanggal & Tempat & Waktu \\
\hline 1 & Senin, 17 Juli 2017 & RA An Nihayyah & $8.30-10.30$ WIB \\
2 & Selasa, 18 Juli 2017 & PAUD Permata Bunda & $9.00-11.00$ WIB \\
3 & Selasa, 25 Agustus 2017 & RA Al Markaz Bengkulu & $8.00-9.15$ WIB \\
\hline
\end{tabular}

Untuk mengumpulkan data di lapangan, peneliti berperan sebagai kolaborator dari kelas Bahasa Inggris dan guru berperan menerapkan bahan ajar yang dikembangkan selama belajar mengajar dalam proses try-out. Di sini, peneliti mengamati efektivitas dari bahan ajar yang dikembangkan, keaktifan para siswa, minat para siswa, pendapat para siswa tentang materi yang dikembangkan, dan lain-lain. Secara umum peneliti melihat bahwa para siswa sangat antusias selama proses belajar mengajar Bahasa Inggris dikelasnya masing-masing.

Peneliti menulis beberapa aspek penting berdasarkan situasi yang terjadi melalui catatan lapangan, sementara para guru sedang mengajar menggunakan bahan dikembangkan. Berdasarkan proses try-out, data dikumpulkan dengan menggunakan kuesioner untuk siswa dan guru yang fokus pada lima poin yang mewakili pendapat siswa tentang materi Bahasas Inggris yang telah dikembangkan. Kelima poin tersebut adalah tentang daya tarik pada bahan ajar, 
tingkat kesulitan, langkah kegiatan, kegunaan bahan dalam meningkatkan motivasi siswa, dan aspek kepraktisan (lihat lampiran).

Berdasarkan data yang dikumpulkan dari 60 siswa melalui gurunya pada sekolah masingmasing (lihat lampiran), ditemukan bahwa ada hampir keseluruhan dari mereka menyatakan bahwa daya tarik pada bahan yang dikembangkan sangat baik. Bahan-bahan yang mereka pelajari dalam proses try-out bisa membuat mereka lebih aktif dalam belajar bahasa Inggris. Keseluruhan guru menilai bahwa daya tarik dari bahan yang telah dikembangkan adalah sangat baik. Mereka mengklaim bahwa daya tarik tersebut dapat memotivasi siswa mereka untuk belajar Bahasa Inggris.

Pada aspek tingkat kesulitan materi yang dikembangkan, 5 guru menyatakan bahwa bahan ajar yang dikembangkan tidak terlalu sulit dan bisa dipahami dengan baik dalam rangka meningkatkan keterampilan siswa mereka dalam Bahasa Inggris, terutama selama proses belajar mengajar di kelas. Disisi lain, terdapat 1 guru yang mengatakan bahwa bahan dikembangkan cukup sulit untuk dipahami terutama jika diberikan pada murid-murid disekolahnya. Ketika peneliti menanyakan seperti apa kesulitan yang mereka temui, guru tersebut mengatakan bahwa ada beberapa kata-kata yang begitu familiar bagi siswanya, sehingga siswanya merasa kesulitan untuk memahami materi.

Pada aspek langkah kegiatan, seluruh guru kompak mengatakan bahwa langkah-langkah kegiatan dan sistematikal dalam bahan ajar yang dikembangkan sangat baik. Materi-materi yang disusun dengan urutan yang logis dan baik. Tidak terdapat satupun dari mereka yang mengatakan bahwa langkah- angkah dan sistematikal bahan ajar yang sudah dikembangkan tidak baik. Dalam hal ini berarti para peneliti berhasil memenuhi kebutuhan dari para guru dan siswa sesaui dengan analisis kebutuhan.

Pada aspek kegunaan dari bahan ajar yang sudah dikembangkan dalam mendukung motivasi siswa dalam mempelajari berbahasa Inggris, keseluruhan responden menyatakan bahwa aspek kegunaan bahan-bahan yang dikembangkan sangat baik dan tidak ada mahasiswa yang mengatakan bahwa aspek kegunaan dari bahan ajar ini cukup atau kurang baik.

Aspek terakhir yang mewakili pendapat siswa dan guru tentang materi yang dikembangkan setelah di laksanakannya try-out adalah aspek kepraktisan. Pada aspek kepraktisan, seluruh responden kompak menyatakan bahwa aspek kepraktisan bahan-bahan yang dikembangkan adalah sangat baik 


\section{Revisi Setelah Try-Out}

Setelah try-out dan mengumpulkan data dari kuesioner, peneliti merevisi kekurangan dan kelemahan dari bahan yang dikembangkan. Kelemahan dari produk animasi dan lembar kerja siswa ini seperti pengayaan materi yang dinilai logis dan layak untuk diajarkan pada siswa level usia dini.

Setelah bahan yang dikembangkan direvisi dan dianggap baik, peneliti berkonsultasi tentang bahan yang dikembangkan dengan ahli. Dari sudut pandang para ahli, bahan ajar yang dikembangkan yang telah direvisi menjadi lebih sempurna dan memenuhi syarat untuk kebutuhan para siswa usia dini dalam belajar Bahasa Inggris.

\section{Final Product}

Langkah terakhir dari penelitian ini adalah produk akhir dari bahan ajar Bahasa Inggris yang dikembangkan sesuai dengan saran dan revisi setelah divalidasi oleh dua orang ahli yang memang kompeten dibidangnya. Para ahli menyetujui produk akhir dari bahan yang dikembangkan ini dan mereka menyatakan bahwa produk penelitian ini benar-benar penting bagi para para siswa Raudhatul Athfal sederajat di kota Bengkulu, karena bahan ini sangat berguna bagi para siswa untuk memecahkan masalah mereka dalam pembelajaran Bahasa Inggris. Produk akhir dari penelitian ini adalah seperangkat bahan ajar tambahan Bahasa Inggris untuk para siswa Raudhatul Athfal di Kota Bengkulu. Bahan ajar tambahan yang telah dikembangkan oleh para peneliti terdiri dari video animasi dua dimensi (2D) dan lembar kerja siswa.

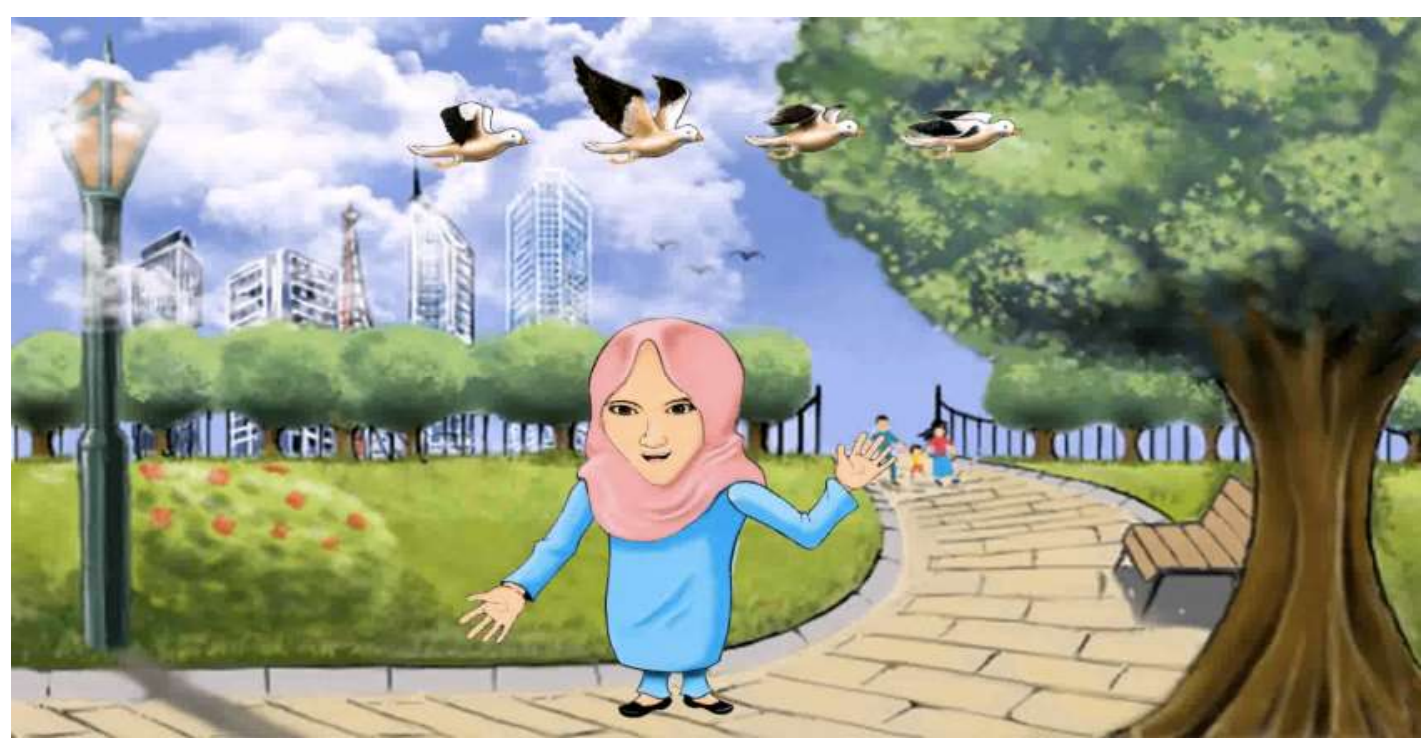

Gambar 1: Video Animasi Dua Dimensi (2D) Hasil Penelitian Pengembangan

Pengembangan Materi Ajar Animasi Bahasa Inggris Bagi Siswa Usia Dini di Kota Bengkulu
Asiyah, Fatrica Syafri dan M. Arif Rahman Hakim 


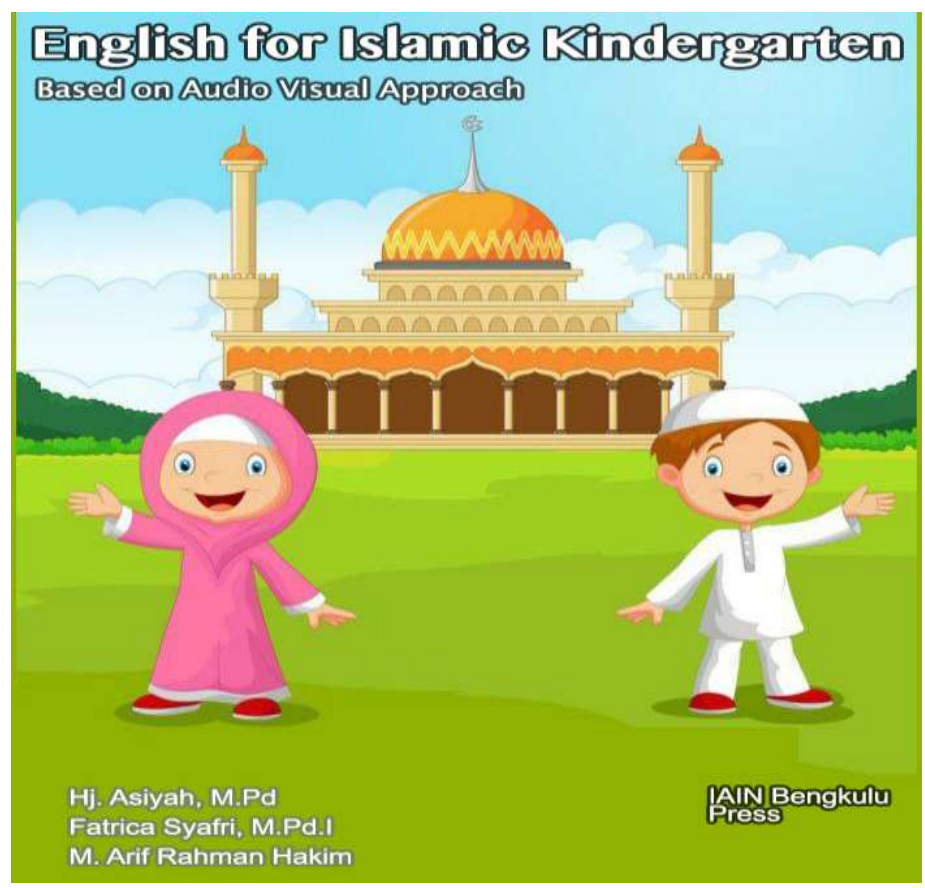

Gambar 2: Lembar Kerja Siswa Hasil Penelitian Pengembangan

\section{SIMPULAN}

Dalam penelitian ini, bahan ajar yang dikembangkan adalah dalam bentuk bahan ajar tambahan yang melengkapi dan menutupi kekurangan dari bahan ajar utama dari subjek Bahasa Inggris yang dikembangkan berdasarkan kebutuhan siswa dan guru pada Raudhatul Athfal sederajat di kota Bengkulu. Bahan ajar tambahan yang dikembangkan juga bertujuan untuk membantu guru Bahasa Inggris yang dapat mengcover kekurangan dalam materi utama yang digunakan para guru dan dimaksudkan untuk memecahkan masalah para guru dan siswa dalam pembelajaran Bahasa Inggris di Raudhatul Athfal sederajat di kota Bengkulu.

Kendala yang terjadi selama proses penilaian kebutuhan seperti heterogenitas pendapat para guru tentang kebutuhan bahan ajar Bahasa Inggris yang membuat para peneliti sedikit merasa kebingungan dalam menentukan materi yang akan dikembangkan. Oleh karena itu, peneliti mengambil pendapat mereka tentang kebutuhan bahan ajar Bahasa Inggris untuk siswa usia dini berdasarkan pilihan utama mereka yang disampaikan melalui kuesioner dan wawancara. Dalam penelitian ini, bahan ajar yang dikembangkan hanya di uji cobakan hanya satu kali karena keterbatasan waktu. Oleh karena itu, peneliti telah mengembangkan bahan ajar yang sesuai dengan materi yang dibutuhkan oleh para guru dan layak dipelajari oleh para siswa. 
Setelah divalidasi oleh para ahli, peneliti melaksanakan try-out pada tiga sekolah, yaitu RA An Nihayyah, RA AL Markaz dan PAUD Permata Bunda dengan jumlah total sebanyak 60 siswa. Hal ini dilaksanakan untuk mengetahui kesesuaian dengan kebutuhan para siswa, efektivitas, kekuatan dan kelemahan dari bahan ajar yang dikembangkan, dan direvisi berdasarkan verifikasi para ahli dan hasil try-out, maka produk akhir dari penelitian ini terdiri dari jenis yaitu animasi dua dimensi dan lembar kerja siswa.

Kekuatan bahan ajar yang dikembangkan adalah bahan ajar ini dikira dapat menutupi kekurangan atau kelemahan bahan ajar utama yang digunakan oleh para guru dimana bahan ajar tersebut belum bisa memenuhi kebutuhan para siswanya secara maksimal dalam belajar Bahasa Inggris disekolahnya masing-masing. Bahan ajar yang dikembangkan di susun secara menarik dan sesuai dengan kebutuhan para siswa yang dapat membuat mereka memiliki motivasi dalam belajar serta dapat diterapkan dalam komunikasi kehidupan nyata.

\section{DAFTAR PUSAKA}

Amelia, R. (2012). "Merancang Pembelajaran Bahasa Inggris Berbabasis Pembelajaran Islami”, dalam Jurnal Pemikiran Islam, 37 (1), 8-15

Bartels, N. (2005). Applied Linguistics and Language Teacher Education. New York: Springer

Bilbrough, N. (2007). Dialogue Activities to Exploring Spoken Interaction in the Language Class. Cambridge: Cambridge University Press

Brown, H.D., Gillian and Yule, George. 1999. Teaching the spoken Language. Cambridge University Press

Borg, W.R. (2012). Applying Educational Research. New York: Longman

Cameron, L. (2001). Teaching Languages to Young Learners. Cambridge: University Press.

Hakim, M.A.R. (2015). "Experienced Efl Teachers' Challenges and Strategies in Teaching Speaking for Introvert Students", dalam European Journal of Social Science, 48 (4), 437-446

Hakim, M.A.R \& Dian. A. (2015). "Developing English Text Book For Fourth Grade Students in Elementary School" dalam International Journal of Educational Studies, 12 (3), 2935

Hughes, R. (2006). Spoken English, TESOL, and Aplied Linguistics. New York: Palgrave Macmillan 
Kabilan, M. K., Ahmad, N., \& Abidin, M. J. Z. (2010). "Facebook: An online environment for learning of English in institutions of higher education?" dalam Internet and Higher Education, 13, 179-187.

Kardimin. 2013. English For Islamic Studies. Yogyakarta: Pustaka Pelajar

Kovalanein, N., \& Katja, K. (2012). "The Role of Shared Foreign Language in Intercultural Communication: A Case of Working Environment" dalam International Journal of Humanities and Social Science, 2(20), 52-72.

Latief, M.A. (2012). Research Method on Language Learning: An Introduction. Malang: UM Press

Leo, S. (2013). A Challenging Book to Practice Teaching in English. Yogyakarta: Penerbit Andi

Littlewood, W. (2002). Communicative Language Teaching. Cambridge: Cambridge University Press

Mihalicek. V., \& Christin. W. 2011. Language Files : Materials for an Introduction to Language and Linguistics. Ohio: Ohio State University

Miller, J., \& Weinert, R. (1998). Spontaneous Spoken Language. New York: Clarendon Press Oxford

Murray, D.E \& Mary, A.C. (2010). What English Language Teachers Need to Know. New York: Rotledge.

Nisak, R. (2014). Seabrek Games Asyik-Edukatif Untuk Mengajar PAUD/TK. Jogjakarta: Diva Press

Paul Suparno. Prof. (2003). Teori Perkembangan Kognitif Jean Piaget. Yogyakarta: Kanisius.

Puspita, $R$ \& Ernilis. (2013). “Upaya Peningkatan Kemampuan Kosa Kata Bahasa Inggris Anak Melalui Strategi Bermain Aktif” dalam Antologi PGPAUD, 1(3), 1-7

Santrock, J.W. (2007). Child Development, Taxas: McGraw-Hillswẹt, Penny. (1996). A Course in Language Teaching. Cambridge : Cambridge

Santrock, J.W. (2014). Educational Psychology. New York: McGraw Hill

Sari, R. 2007. Pembelajaran Bahasa Inggris Pendekatan Qur'ani. Malang: UIN Malaiki Press

Syamsu. (2004). Psikologi Perkembangan Anak dan Remaja. Bandung: Remaja Rosdakarya

Suyanto, K.K.E. (2008). English For Young Learners. Bumi Aksara: Jakarta

Tarigan, H.G. (2008). Berbicara Sebagai Suatu Keterampilan Berbahasa. Bandung: Angkasa

Pengembangan Materi Ajar Animasi Bahasa Inggris Bagi $\begin{array}{r}\text { Asiyah, Fatrica Syafri dan M. Arif } \\ \text { Siswa Usia Dini di Kota Bengkulu }\end{array}$


Thornbury, S and Slade, D. 2006. Conversation: From Description to Pedagogy. Cambridge: Cambridge University Press

Tillit, B., \& Bruder, M.N. (1999). Speaking Naturally. Cambridge: Cambridge University Press

Yusuf Al-Qardhawi, Pendidikan Islam dan Madrasah Hasan Al-Banna, terj. Prof. H. Bustami A. Gani dan Drs.Zainal Abidin Ahmad (Jakarta: Bulan Bintang, 1980) h.157 isçp:

Vygotsky, L.S. (1986). Thought and Language. Cambridge, M.A. : The MIT Press. 